\title{
Expression analysis of host defense responses against the 8K (KDa) cysteine-rich viral silencing suppressor protein in Nicotiana benthamiana
}

\author{
Aminallah Tahmasebi* ${ }^{1}$, Alireza Afsharifar ${ }^{1}$, Ahmad Heydari ${ }^{2}$, Mohammad Mehrabadi ${ }^{3}$ \\ ${ }^{1}$ Plant Virology Research Center, College of Agriculture, Shiraz University, Shiraz, Iran \\ ${ }^{2}$ Firoozabad Center for Higher Education, Iran \\ ${ }^{3}$ Department of Entomology, Faculty of Agriculture, Tarbiat Modares University, Tehran, Iran
}

*Corresponding author: Tahmasebi.info@yahoo.com

\begin{abstract}
Potato mop-top virus (PMTV) encodes the $8 \mathrm{~K}$ cysteine-rich viral suppressor of RNA silencing. To gain an insight into N. benthamiana defense mechanisms against $8 \mathrm{~K}$ suppressor protein, we expressed two $8 \mathrm{~K}$ suppressors from Peruvian isolates in Nicotiana benthamiana and assessed the expression of its defense genes involved in autophagy (ATG6, ATG2 and ATG7, AGO1), salicylic acid (SA) (ICS1, NPR1 and PR1) and jasmonic acid (JA) (OPR3, COI1 and PDF1.2) pathways. To do this, the 8K cDNAs of two Peruvian PMTV isolates were cloned in pGWB17 vector with a C-terminal myc tag and N-terminal 35S promoter using Gateway technology. Agrobacterium cultures harboring PMTV $8 \mathrm{~K}$ were syringe infiltrated into the abaxial side of $N$. benthamiana leaves. The expression levels of defense genes were examined in $N$. benthamiana leaves infiltrated with P1 8K, P11 8K and the control constructs at 2 and 5 days post infiltration in response to PMTV 8Ks using q-PCR technique. Our results showed that the expression levels of ATG6, ATG2, ATG7, ICS1, OPR3, NPR1, PR1, COI1 and PDF1.2 were increased in response to both 8K suppressors. However, the transcript level of Argonaute1 (AGO1) was decreased in response to both $8 \mathrm{~K}$ suppressors compared with the control. These results indicated that $8 \mathrm{~K}$ suppressor proteins can alter the expression of autophagy, SA and JA signaling pathway genes in $N$. benthamiana. Taken together, it seems that despite the $8 \mathrm{~K}$ role in virus pathogenicity, it can also induce host defense responses to modulate plant-virus interactions and fine-tune host-virus coexistence.
\end{abstract}

Keywords: Coevolution, Defense responses, Gene expression, 8K, Potato mop-top virus, RNA silencing suppressor. Abbreviations: JA_Jasmonic acid; PMTV_Potato mop-top virus; SA_Salicylic acid; VSR_Viral suppressor of RNA silencing.

\section{Introduction}

PMTV is a member of Pomovirus genus causing brown arcs and circles in potato tubers that make them unmarketable. The tripartite PMTV genome consists of three singlestranded RNAs with totally eight open reading frames (ORFs). RNA1 and RNA2 function in virus replication and encapsidation/transmission, respectively (Savenkov et al., 1999; Sandgren et al., 2001). RNA3 encodes a triple gene block (TGB) and a cysteine-rich protein, 8K (8kDa) (Savenkov, 2002). Three TGB proteins are responsible for viral cell-tocell movement in plants (Morozov and Solovyev, 2003; Zamyatnin et al., 2004). $8 \mathrm{~K}$ protein increases the virulence of PMTV and also acts as a viral suppressor of RNA silencing (VSR) (Lukhovitskaya et al., 2005; Lukhovitskaya et al., 2013). VSRs can block host antiviral RNA silencing pathway at different levels (Pumplin and Voinnet, 2013). For example, VSRs degrade Argonaute1 (AGO1) protein through an autophagy based-system for the inactivation of the plant RNA silencing machinery (Derrien et al., 2012). AGO1 as a component of RISC (RNA-induced silencing complex) guides the sequence-specific degradation of the homologous viral RNAs (Baumberger and Baulcombe, 2005).

Autophagy can act as a plant defense system against VSRs by modulation of plant-pathogen interaction via a number of plant defense pathways including SA, JA and RNA silencing (Zhou et al., 2014; Nakahara et al., 2012). The SA and JA phytohormones participate in antiviral plant defense responses and their levels change in response to virus infections (Alazem and Lin, 2015). On the other hand, VSRs are also capable of regulating plant defense pathways including SA and JA signaling (Westwood et al., 2014).

Since the origin of potato lies in Peru (Spooner et al., 2005), it is common to find the greatest variability of potato viruses there (Hooker, 1982). The Peruvian PMTV isolates showed the highest variability compared to other worldwide isolates and the susceptibility of potato commercial cultivars was also confirmed in response to Peruvian PMTV isolates (Tenorio et al., 2006). Consequently, the $8 \mathrm{~K}$ protein variability was much greater among Peruvian isolates than that in worldwide isolates (Kalyandurg et al., 2017).

Although the role of $8 \mathrm{~K}$ protein in PMTV-host interactions has been studied, little is known about host plant responses to this viral protein. Therefore, in this study we investigated plant host defense responses against $8 \mathrm{~K}$ suppressors by expression of $8 \mathrm{~K}$ from two Peruvian isolates in $N$. benthamiana. Understanding of networks involved in the 
virus-plant interactions could help in the dissection of the plant defense mechanisms against viruses.

\section{Results and Discussion}

\section{Transcript analysis of autophagy-related genes}

The transcript levels of ATG6, ATG2 and ATG7 were increased in P1 8K treatment by 7.6, 2.5, 5.2-fold and in P11 $8 \mathrm{~K}$ treatment by $1.1,12.2,4.8$-fold, respectively, when compared with their counterparts in infiltrated leaves with control constructs (Fig. 2). It has been shown that PMTV $8 \mathrm{~K}$ is associated with endoplasmic reticulum (ER)-membranes and its expression induces rearrangements of the ER membranes in plant cells (Lukhovitskaya et al., 2005). Autophagosomes can arise from extending membranes of several sources including the ER (Hamasaki et al., 2013). Autophagy might act as a defense system against VSRs (Nakahara et al., 2012). The enhancement of ATG6, ATG2 and ATG7 expressions might be as a result of inducing plant antiviral autophagy process in response to 8K suppressors. Our results were in agreement with other studies which showed that autophagy genes were up-regulated in response to plant viruses and VSRs (Tahmasebi et al., 2017; Liu et al., 2005; Liu et al., 2014; Miozzi et al., 2014; AscencioIbáñez et al., 2008). The induced autophagy can limit virus replication and/or spread either through degradation of viruses or via its effects on other antiviral defense pathways (Agius et al., 2012).

The transcript level of $A G O 1$, a key component of RISC was decreased by 39.9- and 30.6-fold lower than that of AGO1 in infiltrated leaves without P1 $8 \mathrm{~K}$ and P11 8K, respectively (Fig. 2). This result was in accordance with other studies which showed that VSRs repressed the AGO1 (Derrien et al., 2012; Azevedo et al., 2010; Giner et al., 2010; Zhang et al., 2006; Chiu et al., 2010; Várallyay et al., 2010). VSR-mediated control of AGO1 can be a mechanism to alleviate the action of RNA silencing-based defenses through a reduction in RISC formation.

\section{Quantitative measurement of relative expression of SA and JA-related genes}

The expression levels of the SA and JA upstream genes, ICS1 and OPR3 were increased by 6.2 and 2.6-fold in P1 8K and 13.2 and 4.9-fold, in $\mathrm{P} 11$ 8K, respectively, in comparison to the level of genes in the control infiltrated leaves (Figs. 3 and 4). The transcript levels of SA downstream genes (NPR1 and $P R 1$ ) were also found to be upregulated by 5.92- and 1.55fold in $\mathrm{P} 18 \mathrm{~K}$ and 2.3-and 1.1-fold in P11 8K, respectively (Fig. 3). Moreover, JA downstream genes (COI1 and PDF1.2) were also upregulated by 1.72 and 4.86 -fold in $\mathrm{P} 18 \mathrm{~K}$ and 1.63- and 1.92-fold in P11 8K, respectively (Fig. 4).

In addition to defense against VSRs, autophagy can also affect other plant defense pathways including hypersensitive cell death, SA- and JA-based defense (Nakahara et al., 2012). We showed that expression of $8 \mathrm{~K}$ enhanced transcript level of SA-related genes (ICS1, NPR1 and PR1). Similar to our results, it has been shown that the plants expressing $2 b$ transgenes induce SA accumulation (Lewsey et al., 2010). SA accumulation can cause increased reactive oxygen species production and necrosis in $N$. benthamiana. TMV (PMTV-8K) caused necrosis on the inoculated $N$. benthamiana leaves
(Lukhovitskaya et al., 2005). On the other hand, systemic necrosis can increase SA biosynthesis (Jovel et al., 2011). Therefore, it can be hypothesized that SA accumulation in response to $8 \mathrm{k}$ protein might be associated with $\mathrm{HR}$ suppression and necrosis induction in $N$. benthamiana in response to $8 \mathrm{~K}$. We also found that JA-related genes (OPR3, COI1 and PDF1.2) were up-regulated in response to both $8 \mathrm{~K}$ suppressors. These results are in line with other reports which showed that expression of HC-Pro from Tobacco etch virus and the P6 from Cauliflower mosaic virus enhanced JA responses in Arabidopsis thaliana (Endres et al., 2010; Love et al., 2012). Enhanced expression of SA- and JA-related genes can be as a result of induction of autophagy pathway. The results indicate that $8 \mathrm{~K}$ may itself be the target of host defense responses.

\section{Materials and Methods}

\section{Plant and growth conditions}

$N$. benthamiana plants were grown in a greenhouse under long day ( $16 \mathrm{hr}$ light/8 hr dark) photoperiodic conditions at $18^{\circ} \mathrm{C} \pm 4^{\circ} \mathrm{C}$ and $80 \%$ relative humidity.

\section{Transient expression assay in N. benthamiana}

The cDNAs encoding the $8 \mathrm{~K}$ protein of two PMTV isolates from Peru (P1, KU955501 and P11, KU955498 accession numbers) were PCR amplified (Fig. 1) using full-length clones (provided by Eugene Savenkov) and specific primers (Table 1) followed by cloning into a pDONRTM/Zeo vector (Invitrogen) (Earley et al., 2006). Following confirmation of the clones' identity by sequencing, they were recombined into the Gateway (Invitrogen) destination vector pGWB17 (Nakagawa et al., 2007), with a C-terminal myc tag and Nterminal $35 \mathrm{~S}$ promoter to generate $\mathrm{pBin} 8 \mathrm{~K}$ for agroinfiltration test. Wild-type $N$. benthamiana plants were used for agro-infiltration tests (Ruiz et al., 1998). Leaves of $N$. benthamiana which were divided into two equal parts were infiltrated with $A$. tumefaciens cells harboring pGWB17 8K and opposite side of leaf was infiltrated with the pGWB plasmid. pGWB plasmid construct was used as a negative control in gene expression analysis.

\section{RNA extraction and CDNA synthesis}

Total RNAs from infiltrated leaves with $A$. tumefaciens cells harboring pGWB17 $8 \mathrm{~K}$ or pGWB constructs were extracted with the total RNA kit (S-1010-1, Dena Zist Asia, Iran) with DNase I (Invitrogen) according to the manufacturer's instruction. Total RNA concentrations were measured with a ND-1000 spectrophotometer (Nanodrop, Wilmington, DE, U.S.A.), and one-microgram aliquots of total RNA samples were used for cDNA synthesis with the iScript reverse transcriptase first-strand cDNA synthesis kit (MBI, Fermentas). cDNA was synthesized using $1 \mu \mathrm{l}$ of oligo (dT) primer $(0.5 \mu \mathrm{g} / \mu \mathrm{l}), 4 \mu \mathrm{l}$ of $5 \mathrm{x}$ reaction buffer, $1 \mu \mathrm{l}$ of Revert AidTM M-MuLV reverse transcriptase (Invitrogen) and $9 \mu \mathrm{l}$ of DEPC- treated water and $2 \mu \mathrm{l}$ of $10 \mathrm{mM}$ dNTP mix. The mixture was incubated at $42^{\circ} \mathrm{C}$ for $30 \mathrm{~min}$, and then $5 \mathrm{~min}$ at $80^{\circ} \mathrm{C}$. 
Table 1. Nucleotide sequences of specific primer pairs which were used in this study for amplification of DNA fragment of 8K gene of PMTV isolates (product sizes are shown).

\begin{tabular}{|c|c|c|c|c|}
\hline Template & & Primer Sequence ( $5^{\prime}$ to $\left.3^{\prime}\right)$ & PCR & $\begin{array}{l}\text { product } \\
\text { Size (bp) }\end{array}$ \\
\hline \multirow[t]{2}{*}{$8 \mathrm{~K} \mathrm{P1}$} & $\mathrm{F}$ & GGGGACAAGTTTGTACAAAAAAGCAGGCTTGATGGAA & & 265 \\
\hline & $\mathrm{R}$ & GGGGACCACTTTGTACAAGAAAGCTGGGTAACGGCAT & & \\
\hline \multirow[t]{2}{*}{$8 \mathrm{~K}$ P11 } & $\mathrm{F}$ & GGGGACAAGTTTGTACAAAAAAGCAGGCTTGATGGAA & & 265 \\
\hline & $\mathrm{R}$ & GGGGACCACTTTGTACAAGAAAGCTGGGTAACGGCAT & & \\
\hline
\end{tabular}

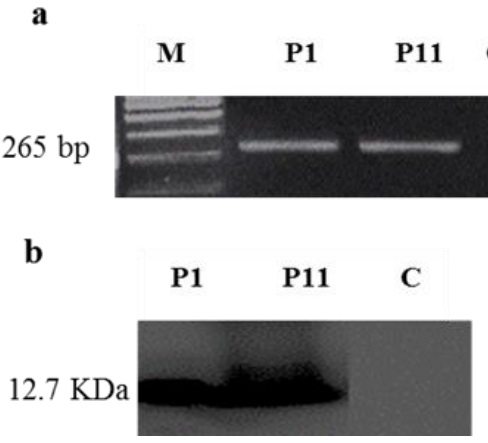

Fig 1. Gel electrophoresis pattern of PCR products for amplification of $8 K$ gene of PMTV isolates (a) using specific primer pair (Table 1). Lane $\mathrm{M}$ represents the Gene Ruler $1 \mathrm{~kb}$ plus DNA Ladder. Western blot detection of the $8 \mathrm{~K}$ proteins in the N. benthamiana leaves infiltrated with Agrobacterium constructs containing 8K P1, 8K P11 and C, control) (b). A total of $30 \mu \mathrm{g}$ extracts for each sample was prepared and subjected to immunoblot analysis with myc tag-specific antibody.

Table 2. Features of specific primers used in expression of genes involved in autophagy process (ATG6, ATG, ATG7 and AGO1), SA (ICS1, NPR1 and PR1) and JA (OPR3, COI1 and PDF1.2) signaling pathways.

\begin{tabular}{|c|c|c|c|c|}
\hline Gene name & $\begin{array}{l}\text { Primer } \\
\text { name }\end{array}$ & Sequence from $5^{\prime}$ to $3^{\prime}$ & PCR product Size (bp) & Accession number \\
\hline \multirow[t]{2}{*}{$A G 01$} & AG01-F & GCCATGGGGCACCTTCTG & 132 & KR942296.1 \\
\hline & AG01-R & GAGACGAGGAACCAGCCTC & & \\
\hline \multirow[t]{2}{*}{ ATG6 } & ATG6-F & ACCTGCGTAAAGGAGTTTGCTGAC & 164 & AY701316.1 \\
\hline & ATG6-R & AGAGCTTTGGTCCAACTTTCCTGC & & \\
\hline \multirow[t]{2}{*}{ ATG2 } & ATG2-F & GCAATTGGGCTTGGAGTGCATTTG & 159 & KR336559.1 \\
\hline & ATG2-R & CCTGTCGGGCATCTCTAGGTTGAT & & \\
\hline \multirow[t]{2}{*}{ ATG7 } & ATG7-F & CCAGCAGTGGAAGCAGAAGGTCTT & 166 & KX369398.1 \\
\hline & ATG7-R & GCCACCGACTTTCCCGTGTATCA & & \\
\hline \multirow[t]{2}{*}{ COI1 } & COI1-F & CACTTGATAATGGTGT & 172 & AY547493.1 \\
\hline & COI1-R & AGGCCTTCATCGGATTCC & & \\
\hline \multirow[t]{2}{*}{ NPR1 } & NPR1-F & TGCATGTTGCAGCTATGAGGA & 156 & KY402167.1 \\
\hline & NPR1-R & CTTCCTCCGGAGACTTGCTG & & \\
\hline \multirow[t]{2}{*}{ PR1 } & PR1-F & CGACCAGGTAGCAGCCTATG & 140 & JN247448.1 \\
\hline & PR1-R & TCTCAACAGCCTTAGCAGCC & & \\
\hline \multirow[t]{2}{*}{ OPR3 } & OPR3-F & GTGGAGCTGCACCAATATCT & 149 & NM_001325344.1 \\
\hline & OPR3-R & TGCCTTGCGATAATCTTCAACC & & \\
\hline \multirow[t]{2}{*}{ ICS1 } & ICS1-F & TTCAGTCTGGAGTCTCCCCC & 102 & LC222288.1 \\
\hline & ICS1-R & GCTGTGTGTTCCAGCGTTTTA & & \\
\hline \multirow[t]{2}{*}{ PDF1.2 } & PDF1.2-F & GACCAACGACAATTGCAGAGG & 100 & KP017278.1 \\
\hline & PDF1.2-R & GTCAAACAGACGGTGGCACA & & \\
\hline \multirow[t]{2}{*}{$E F 1-\alpha$} & EF1- $\alpha-F$ & AGCTTTACCTCCCAAGTCATC & 135 & NM_001326165.1 \\
\hline & EF1- $\alpha-R$ & AGAACGCCTGTCAATCTTGG & & \\
\hline
\end{tabular}



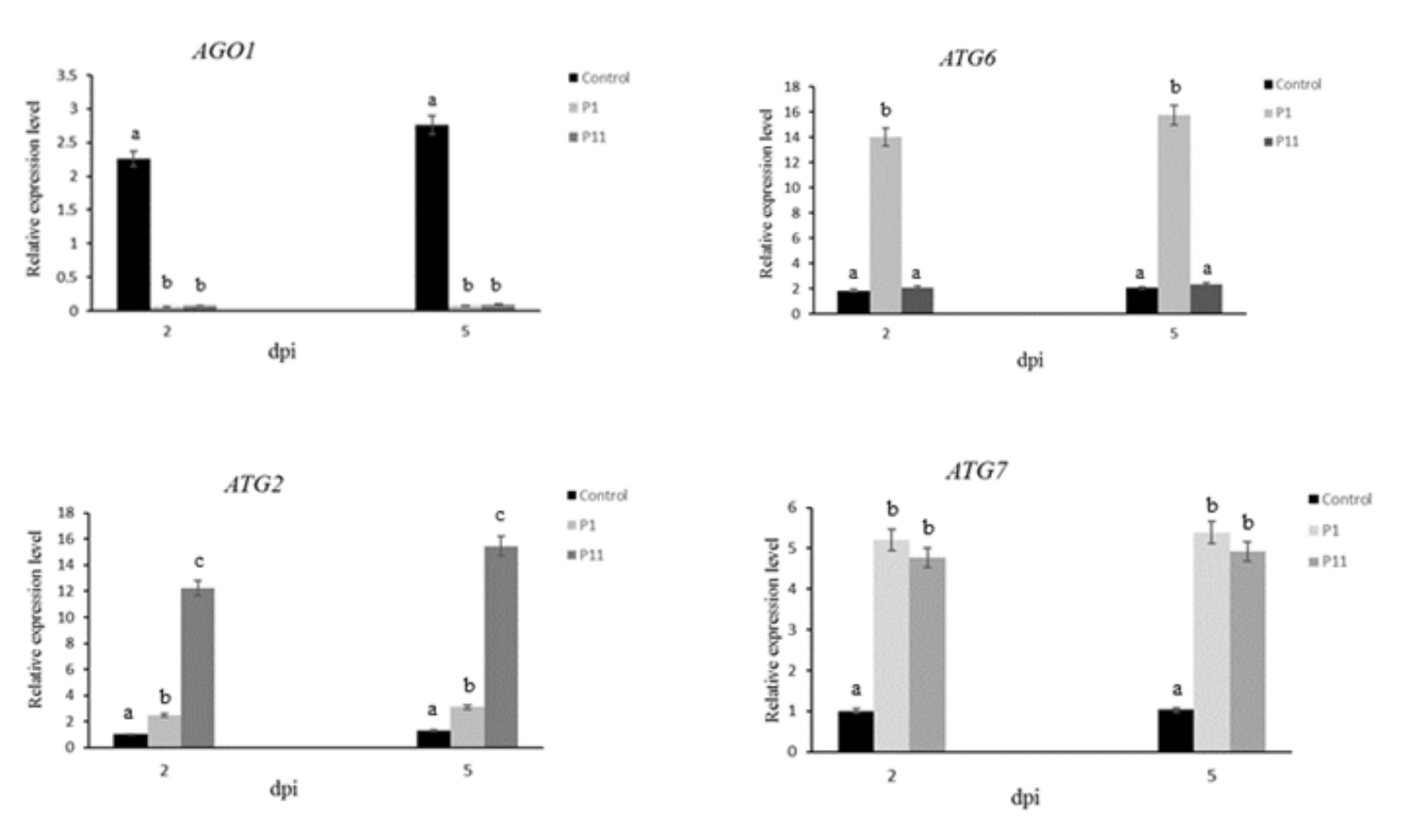

Fig 2. Accumulation level of autophagy-related genes (ATG6, ATG2, ATG7 and AGO1) in N. benthamiana leaves infiltrated with P1 $8 \mathrm{~K}, \mathrm{P} 118 \mathrm{~K}$ and control constructs at 2 and 5 days post infiltration (dpi), measured by qPCR. Mean was obtained from three biological replicates. Error bars are representative of the standard error (Mean $\pm S D, n=3$ ). Different letters indicate statistically different values $(P, 0.05$, Duncan test).
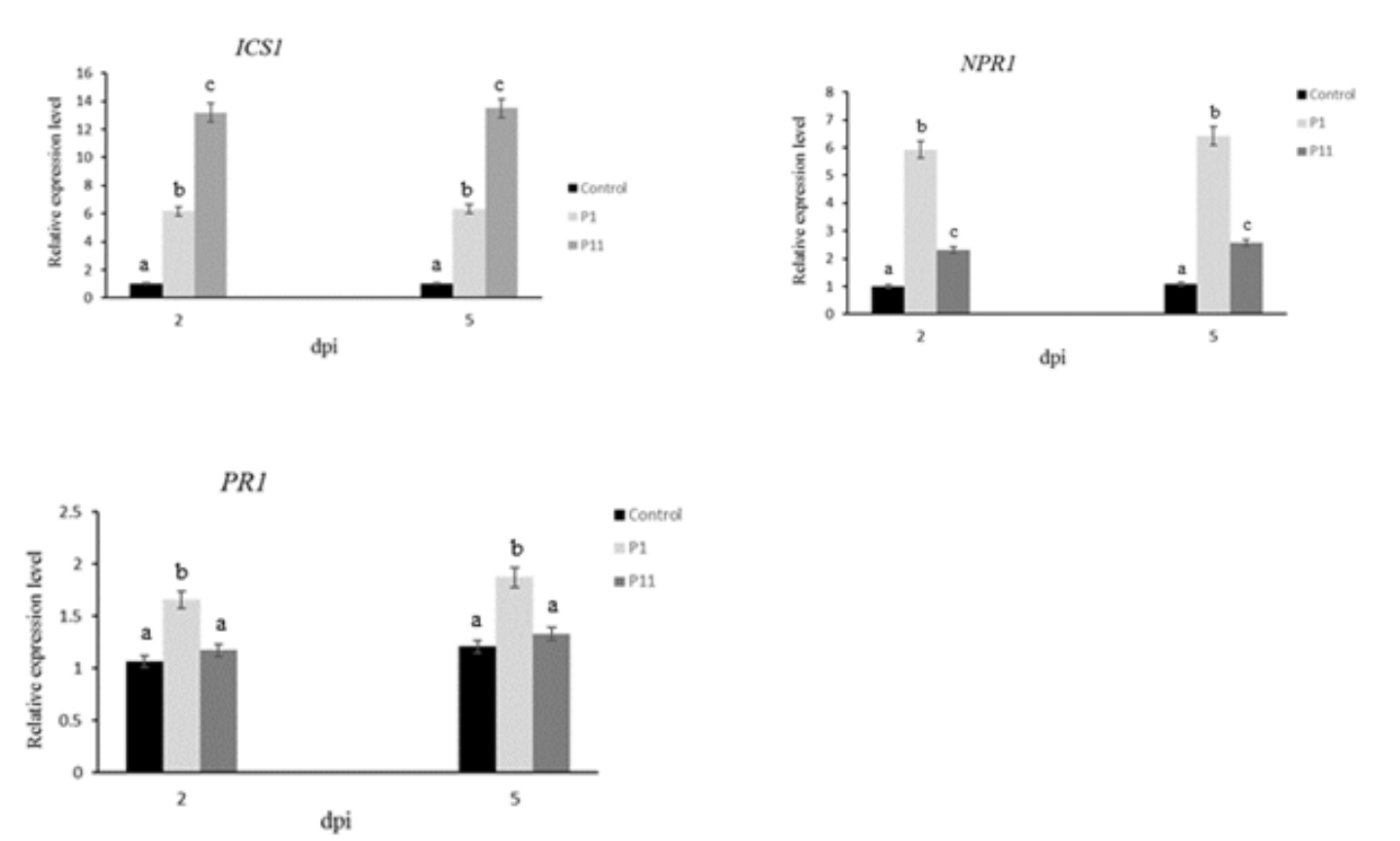

Fig 3. Accumulation level of SA-related genes (ICS1, NPR1 and PR1) in N. benthamiana leaves infiltrated with P1 8K, P11 8K and control constructs at 2 and 5 days post infiltration (dpi), measured by qPCR. Mean was obtained from three biological replicates. Error bars are representative of the standard error (Mean $\pm \mathrm{SD}, \mathrm{n}=3$ ). Different letters indicate statistically different values $(P$, 0.05 , Duncan test). 


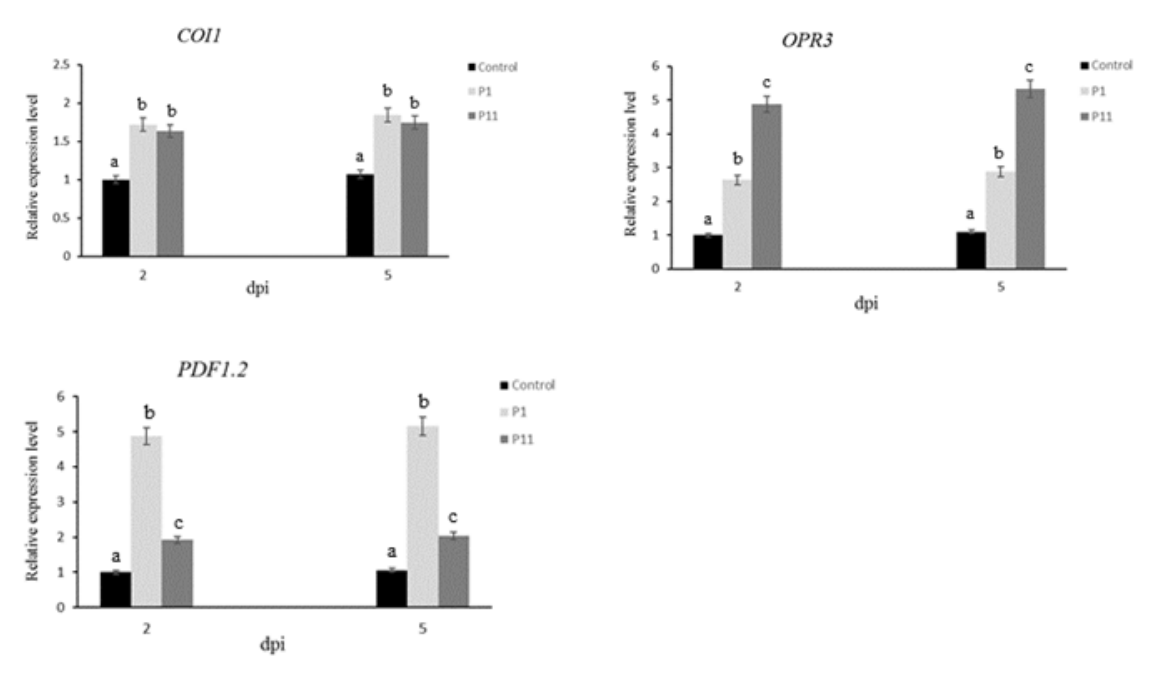

Fig 4. Accumulation level of JA-related genes (OPR3, COI1 and PDF1.2) in N. benthamiana leaves infiltrated with P1 8K, P11 8K and control constructs at 2 and 5 days post infiltration (dpi), measured by qPCR. Mean was obtained from three biological replicates. Error bars are representative of the standard error (Mean $\pm \mathrm{SD}, \mathrm{n}=3$ ). Different letters indicate statistically different values $(P$, 0.05 , Duncan test).

\section{Quantitative Real Time PCR (qPCR)}

The expression level of ten genes involved in defense signaling pathways (Table 2) was analyzed at 2 and 5 days post infiltration (dpi) in response to $\mathrm{P} 18 \mathrm{~K}$ and $\mathrm{P} 118 \mathrm{~K}$ by qPCR using a lineGeneK thermal cycler (Exicycler TM96) apparatus according to the manufacturer's recommendations. The qPCR primers were designed for these genes (Table 2). The qPCR test was performed in a 20 $\mu \mathrm{l}$ volume reaction mixture containing CDNA (250 ng) template, $10 \mu \mathrm{M}$ of each primer $(0.6 \mu \mathrm{l})$, qPCR SYBR ${ }^{\circledR}$ Green master with low ROX (Jena Bioscience, Germany) $(10 \mu \mathrm{l})$ and sterile water (fill up to $20 \mu \mathrm{l}$ ). The genes were analyzed using the following profile: $95^{\circ} \mathrm{C}$ for $2 \mathrm{~min}$, then 40 cycles of $95^{\circ} \mathrm{C}$ for $15 \mathrm{~s}$ and $60^{\circ} \mathrm{C}$ for $1 \mathrm{~min}$. Data were expressed as quantification cycle $(\mathrm{Cq})$. Three biological replicates were used, and three technical replicates were performed for each biological replicate. Accordingly, The fold expression of target mRNAs was calculated using the equation; $2^{-\Delta \Delta C t}$ (Livak and Schmittgen, 2001). EIF1- $\alpha$ was used as an internal reference.

\section{Western blot analysis of $8 K$ protein}

One-hundred milligrams fresh weight of infiltrated $N$. benthamiana leaves were ground and homogenized in 300 $\mu \mathrm{l}$ of laemmli buffer (0.125 M Tris- $\mathrm{HCl}, \mathrm{pH}, 6.8 ; 4 \%$ Sodium dodecyl sulfate (SDS); $10 \% 2$ mercaptoethanol; $20 \%$ glycerol; $0.004 \%$ bromophenol blue), centrifuged for $10 \mathrm{~min}$ at 13,000 rpm. The supernatant was run on a $16 \%$ sodium dodecyl sulphate polyacrylamide gel electrophoresis. Then proteins were transferred onto a PVDF membrane (Sambrook and Russell, 2001). Detection was conducted with the primary mouse myc-specific monoclonal antibody (Roche) (diluted 1:1,000 in PBS-T plus $2.5 \%$ milk) followed by incubation with a secondary anti-mouse polyclonal antibody (diluted 1:5000 in PBS-T plus $2.5 \%$ milk). Signals were detected using the $\mathrm{ECL}$ Prime kit (Amersham, GE Healthcare). The membrane was imaged using a LAS-3000 Luminescent Image Analyzer (Fujifilm, Fuji Photo Film, Kleve, Germany) (Fig. 1).

\section{Statistical analysis}

The data were statistically analyzed using analysis of variance (ANOVA) with subsequent Duncan's multiple range test with SAS 9.4 software and those with $p$-values less than 0.05 were considered significant. All experiments reported in this study were repeated in three biological and technical replicates.

\section{Conclusion}

The results reported herein showed that autophagy, SA and JA-related genes are induced as defense systems in $N$. benthamiana against $8 \mathrm{~K}$ suppressor protein. Besides the $8 \mathrm{~K}$ role in virus pathogenicity, it can also induce host defense responses making it an important multifunctional viral protein that plays a pivotal role in the virus-plant interaction. Identification of defense signaling pathways involved in VSR-plant host interaction might be considered in plant genetic engineering as a novel approach to the control of plant viruses.

\section{Acknowledgements}

This study was financially supported by Plant Virology Research Center, College of Agriculture, Shiraz University, Shiraz-Iran. The authors sincerely thank Dr. Eugene Savenkov for providing $8 \mathrm{~K}$ full-length clones and also Dr. José-Antonio Daròs for insightful comments. 


\section{References}

Agius C, Eamens AL, Millar AA, Watson JM, Wang MB (2012) RNA silencing and antiviral defense in plants. In: Watson JM, Wang MB (eds) Antiviral resistance in plants, Humana press, Totowa, NJ.

Alazem M, Lin NS (2015) Roles of plant hormones in the regulation of host-virus interactions. Mol Plant Pathol. 16:529-540.

Ascencio-lbáñez JT, Sozzani R, Lee TJ, Chu TM, Wolfinger RD, Cella R, Hanley-Bowdoin L (2008) Global analysis of Arabidopsis gene expression uncovers a complex array of changes impacting pathogen response and cell cycle during geminivirus infection. Plant Physiol. 148(1):436454.

Azevedo J, Garcia D, Pontier D, Ohnesorge S, Yu A, Garcia S, Braun L, Bergdoll M, Hakimi MA, Lagrange T, Voinnet $O$ (2010) Argonaute quenching and global changes in dicer homeostasis caused by a pathogen-encoded GW repeat protein. Gene Dev. 24(9):904-915.

Baumberger N, Baulcombe DC (2005) Arabidopsis argonaute1 is an RNA slicer that selectively recruits microRNAs and short interfering RNAs. P Natl Acad Sci USA. 102(33):11928-11933.

Chiu MH, Chen I, Baulcombe DC, Tsai CH (2010) The silencing suppressor $\mathrm{P} 25$ of potato virus $\mathrm{X}$ interacts with argonaute 1 and mediates its degradation through the proteasome pathway. Mol Plant Pathol. 11(5):641-649.

Derrien B, Baumberger N, Schepetilnikov M, Viotti C, De Cillia J, Ziegler-Graff V, Isono E, Schumacher K, Genschik P (2012) Degradation of the antiviral component argonaute1 by the autophagy pathway. P Natl Acad Sci USA. 109(39):15942-15946.

Earley KW, Haag JR, Pontes O, Opper K, Juehne T, Song K, Pikaard CS (2006) Gateway-compatible vectors for plant functional genomics and proteomics. Plant J. 45(4):616629.

Endres MW, Gregory BD, Gao Z, Foreman AW, Mlotshwa S, Ge X, Pruss GJ, Ecker JR, Bowman LH, Vance V (2010) Two plant viral suppressors of silencing require the ethyleneinducible host transcription factor RAV2 to block RNA silencing. Plos Pathog. 6(1):e1000729.

Giner A, Lakatos L, García-Chapa M, López-Moya JJ, Burgyán J (2010) Viral protein inhibits RISC activity by argonaute binding through conserved WG/GW motifs. Plos Pathog. 6(7):e1000996.

Hamasaki M, Furuta N, Matsuda A, Nezu A, Yamamoto A, Fujita N, Oomori H, Noda T, Haraguchi T, Hiraoka Y, Amano A (2013) Autophagosomes form at ER-mitochondria contact sites. Nature. 495(7441):389-393.

Hooker WJ (1982) Virus diseases of potato, Technical Information Bulletin 19. International Potato Center (CIP), Lima, Peru. 17 pp.

Jovel J, Walker M, Sanfaçon H (2011) Salicylic aciddependent restriction of tomato ringspot virus spread in tobacco is accompanied by a hypersensitive response, local RNA silencing, and moderate systemic resistance. Mol Plant Microbe In. 24(6):706-718.

Kalyandurg P, Gil JF, Lukhovitskaya NI, Flores B, Müller G, Chuquillanqui C, Palomino L, Monjane A, Barker I, Kreuze J, Savenkov EI (2017) Molecular and pathobiological characterization of 61 potato mop-top virus full-length cDNAs reveals great variability of the virus in the center of potato domestication, novel genotypes and evidence for recombination. Mol Plant Pathol. 18(6):864-877.

Lewsey MG, Murphy AM, MacLean D, Dalchau N, Westwood JH, Macaulay K, Bennett MH, Moulin M, Hanke DE, Powell G, Smith AG (2010) Disruption of two defensive signaling pathways by a viral RNA silencing suppressor. Mol Plant Microbe In. 23(7):835-845.

Liu L, Chung HY, Lacatus G, Baliji S, Ruan J, Sunter G (2014) Altered expression of Arabidopsis genes in response to a multifunctional geminivirus pathogenicity protein. BMC Plant Biol. 14(1):302.

Liu Y, Schiff M, Czymmek K, Tallóczy Z, Levine B, DineshKumar SP (2005) Autophagy regulates programmed cell death during the plant innate immune response. Cell. 121(4):567-577.

Livak KJ, Schmittgen TD (2001) Analysis of relative gene expression data using real-time quantitative PCR and the 2- ${ }^{\Delta \Delta C T}$ method. Methods. 25(4):402-408.

Love AJ, Geri C, Laird J, Carr C, Yun BW, Loake GJ, Tada Y, Sadanandom A, Milner JJ (2012) Cauliflower mosaic virus protein $\mathrm{P} 6$ inhibits signaling responses to salicylic acid and regulates innate immunity. Plos One. 7(10):e47535.

Lukhovitskaya NI, Thaduri S, Garushyants SK, Torrance L, Savenkov EI (2013) Deciphering the mechanism of defective interfering RNA (DI RNA) biogenesis reveals that a viral protein and the DI RNA act antagonistically in virus infection. J Gen Virol. 87(11):6091-6103.

Lukhovitskaya NI, Yelina NE, Zamyatnin AA, Schepetilnikov MV, Solovyev AG, Sandgren M, Morozov SY, Valkonen JP, Savenkov EI (2005) Expression, localization and effects on virulence of the cysteine-rich $8 \mathrm{kDa}$ protein of potato moptop virus. J Gen Virol. 86(10):2879-2889.

Miozzi L, Napoli C, Sardo L, Accotto GP (2014) Transcriptomics of the interaction between the monopartite phloem-limited geminivirus tomato yellow leaf curl sardinia virus and Solanum lycopersicum highlights a role for plant hormones, autophagy and plant immune system fine tuning during infection. Plos One. 9(2):e89951.

Morozov SY, Solovyev AG (2003) Triple gene block: modular design of a multifunctional machine for plant virus movement. J Gen Virol. 84(6):1351-1366.

Nakagawa T, Kurose T, Hino T, Tanaka K, Kawamukai M, Niwa Y, Toyooka K, Matsuoka K, Jinbo T, Kimura T (2007) Development of series of gateway binary vectors, pGWBs, for realizing efficient construction of fusion genes for plant transformation. J Biosci Bioeng. 104(1):34-41.

Nakahara KS, Masuta C, Yamada S, Shimura H, Kashihara Y, Wada TS, Meguro A, Goto K, Tadamura K, Sueda K, Sekiguchi T (2012) Tobacco calmodulin-like protein provides secondary defense by binding to and directing degradation of virus RNA silencing suppressors. P Natl Acad Sci USA. 109(25):10113-10118.

Pumplin N, Voinnet O (2013) RNA silencing suppression by plant pathogens: defence, counter-defence and countercounter-defence. Nat Rev Microbiol. 11(11):745.

Ruiz MT, Voinnet O, Baulcombe DC (1998) Initiation and maintenance of virus-induced gene silencing. Plant Cell. 10(6):937-946.

Sambrook J, Russell DW (2001) Molecular cloning: a laboratory manual, 3rd edn. Cold pring Harbor Laboratory Press, New York. 
Sandgren M, Savenkov El, Valkonen JP (2001) The readthrough region of potato mop-top virus (PMTV) coat protein encoding RNA, the second largest RNA of PMTV genome, undergoes structural changes in naturally infected and experimentally inoculated plants. Arch Virol. 146(3):467-477.

Savenkov El (2002) Genus Pomovirus. In: Tidona CA, Darai G (eds) The springer index of viruses. Heidelberg, Germany.

Savenkov El, Sandgren M, Valkonen JP (1999) Complete sequence of RNA 1 and the presence of tRNA-like structures in all RNAs of potato mop-top virus, genus Pomovirus. J Gen Virol. 80(10):2779-2784.

Spooner DM, McLean K, Ramsay G, Waugh R, Bryan GJ (2005) A single domestication for potato based on multilocus amplified fragment length polymorphism genotyping. P Natl Acad Sci USA. 102(41):14694-14699.

Tahmasebi A, Afsharifar A, Rabiee S, Izadpanah K (2017) Altered expression of autophagy-related genes in Nicotiana benthamiana plants in response to potato virus A HC-Pro silencing suppressor. Iran J Plant Pathol. 53:6374.

Tenorio J, Franco Y, Chuquillanqui C, Owens RA, Salazar LF (2006) Reaction of potato varieties to potato mop-top virus infection in the andes. Am J Potato Res. 83(5):423431.
Várallyay É, Válóczi A, Ágyi Á, Burgyán J, Havelda Z (2010) Plant virus-mediated induction of mir168 is associated with repression of argonaute1 accumulation. EMBO J. 29(20):3507-3519.

Westwood JH, Lewsey MG, Murphy AM, Tungadi T, Bates A, Gilligan CA, Carr JP (2014) Interference with jasmonic acidregulated gene expression is a general property of viral suppressors of RNA silencing but only partly explains virusinduced changes in plant-aphid interactions. J Gen Virol. 95(3):733-739.

Zamyatnin AA, Solovyev AG, Savenkov El, Germundsson A, Sandgren M, Valkonen JP, Morozov SY (2004) Transient coexpression of individual genes encoded by the triple gene block of potato mop-top virus reveals requirements for TGBp1 trafficking. Mol Plant Microbe In. 17(8):921930.

Zhang $X$, Yuan YR, Pei Y, Lin SS, Tuschl T, Patel DJ, Chua NH (2006) Cucumber mosaic virus-encoded $2 b$ suppressor inhibits Arabidopsis argonaute1 cleavage activity to counter plant defense. Gene Dev. 20(23):3255-3268.

Zhou J, Yu JQ, Chen Z (2014) The perplexing role of autophagy in plant innate immune responses. Mol Plant Pathol. 15(6):637. 